\title{
Liquidity And Bank Performance
}

\author{
Godfrey Marozva, CFA, University of South Africa, South Africa
}

\begin{abstract}
This article is based on empirical research on the relationship between liquidity and bank performance for South African banks for the period between 1998 and 2014. The study employed the Autoregressive Distributed Lag (ARDL)-bound testing approach and the Ordinary Least Squares $(O L S)$ to examine the nexus between net interest margin and liquidity. Liquidity in this article is viewed in the context of the market liquidity risk and funding liquidity risk. The study observes that there is a negative significant deterministic relationship between net interest margin and funding liquidity risk. However, there is an insignificant co-integrating relationship between net interest margin and the two measures of liquidity. Based on this research it is recommended that further research should be conducted to investigate liquidity in the context of asset-liability mismatches. Financial institutions also should realise that liquidity is a short-run phenomenon that has to be analysed as such.
\end{abstract}

Keywords: Liquidity; Net Interest Margin; Bank Performance; Credit Risk; ARDL; OLS

\section{INTRODUCTION}

(C) ver the past six decades since Markowitz's seminal paper of 1952 on portfolio selection, most financial theories and models assumed markets were frictionless, thus, in traditional asset pricing models, liquidity plays no role at all because it is assumed away. The moment these conventions are relaxed, the world changes, though not in an expected way. The vast literature on liquidity and asset pricing argues that liquidity is indeed priced and contains both theoretical models and empirical findings detailing how an asset's liquidity affects expected returns. However, much of this literature utilizes asset only approach and is focused on equities, a relatively liquid asset class (Adler 2012).

During the recent global financial crisis several banks experienced some difficulties because they failed to manage liquidity in a prudent manner. Thus the crisis emphasized the importance of liquidity to the proper functioning of financial markets and the banking sector. Before the financial crisis, financial intermediaries were stable as funding was readily available and at low cost. The rapid reversal in market conditions illustrated how quickly liquidity can evaporate, and that illiquidity can reserve already earned profits as financial institutions are either forced to sell assets well below their market value or borrow at interest rates charges above their weighted return on assets.

Though insufficient liquidity is one of the major reasons for bank failures, holding liquid assets has an opportunity cost of higher returns. Bourke (1989) finds a positive significant link between bank liquidity and profitability. However, in times of instability banks may chose to increase their cash holding to mitigate risk. Unlike Bourke (1989), Molyneux and Thorton (1992) came to a conclusion that there is a negative correlation between liquidity and profitability levels.

The liquidity crisis significantly affected banks' operational environment. In response to the catastrophe, financial bodies such as the Basel Committee for bank supervision advocated for the active management of liquidity risk. Banks are required to hold a considerable position in liquid assets while on the other hand, they are required to be profitable for them to be sustainable. Despite the increased efficiency in many banks resulting from holding higher positions of liquid assets, profitability has severely suffered. Liquidity and profitability are inversely related, when liquidity increases profitability decreases and vice versa while on the other hand, there is a direct relationship between higher risk and higher return, hence the dilemma in liquidity management is finding a balance between liquidity and profitability. 
While it is generally agreed that there is a negative relationship between liquidity and bank profitability there is counter evidence which shows the need to consider the trade off between resilience to liquidity shocks and cost of holding less profitable liquid assets as the later is assumed to impact on the bank's ability to take advantage of opportunities arising in the market which may result in increase in revenue, capital or ability to extend capital credit (Bordeleau and Graham 2010). Banks on the asset side hold low yielding securities such as treasury bills and highly rated short term corporate bonds in order to minimise a scramble for liquidity when credit use increases in time when money is constricted (Holmström and Tirole 1998). Thus in essence a liquid financial institution has a smaller portion of its assets in long term loans and a greater proportion of its assets in short term securities that can be quickly liquidated into cash that can then be loaned out, however a highly liquid bank may mean lack of profitable projects to invest the money.

Given that liquid asset has a low liquidity premium and, therefore, a lower return relative to illiquid assets holding them imposes an opportunity cost on a bank. Liquidity management becomes a very important part in financial management decisions, where the liquidity management efficiency could be achieved by firms that manage a trade-off between liquidity and profitability (Bhunia and Khan 2011). The impact of bank asset liquidity on profitability has of late attracted the interest of academic research, financial market analysts, bank management and bank monitors. Brunnermeier, Krishnamurthy, and Gorton (2013) notes that it's not the level of gearing that is important, but rather the proportion of debt that is comprised of short term demandable deposits. Brunnermeier et al. (2013) argue that if banks hold illiquid assets that are financed by short-term debt in periods when banks run behaviour emerges, this may result in increased systemic risk.

There is a lot of literature that leads to the fact that liquidity crunch was the main cause of the 2009/10 global financial crisis yet very little is known about the nexus between bank performance and liquidity. Of the few studies that have looked at the bank liquidity and bank performance nexus most of them took a theoretical approach and the few studies that attempted to empirically test this phenomenon used net interest margin as the indicator for bank profitability. The linkage between net interest margin and liquidity is unsettled. Maudos and Guevara (2004), and Saunders and Schumacher (2000) found a significant positive relationship between market liquidity risk and net interest income. Drakos (2003) and Hesse (2007), on the other hand, found a negative relationship between net interest margin and liquidity. However, Maudos and Solis (2009) found an insignificant relationship between net interest margin and market liquidity.

The researcher investigated the effects of funding liquidity and market liquidity on bank performance utilising net interest margin as the measure of performance. The evidence was based on South African banks from 1998 to 2014. The Autoregressive Distributed Lag (ARDL) -bound test approach and Ordinary Least Squares (OLS) testing was utilised in an attempt to find if there was a long-run or short-run relationship between bank performance and liquidity. The evidence gathered shows that there is a significant deterministic relationship between net interest margin, funding liquidity, and also that there is insignificant long run relationship between bank performance and liquidity.

The paper is organised in the following manner. Section 2 constitutes a brief discussion of literature and the empirical framework as applied in this article. Section 3 presents the estimation method and empirical results. Finally, conclusions and recommendations are presented and policy implications are drawn in section 4.

\section{LITERATURE REVIEW}

Liquidity though not a new phenomenon in finance literature has no universally accepted definition. Adler (2012) asserts that the lack of agreed-upon definition emanates from the fact that the concept of liquidity arises from different economic perspectives. Liquidity can be defined in the context of how easy a security can be traded and in the context of how easy one can obtain funding to trade a security, the former being called market liquidity and the latter being funding liquidity. The focus of this research will be on both funding and market liquidity. Ideally, market and funding liquidity are complementary since the easier it is to trade security means the easier it is to get funds to trade securities. This literature review will attempt to summarise the impact of liquidity on bank performance, hence the need to look at liquidity as a cost, and as a risk and their impact on net interest margin, return on equity (ROE), return on assets (ROA) and economic value added (EVA). That is, investors need to be rewarded for holding illiquid assets and for the sensitivity of the security to liquidity shocks. 
According to European Central Bank (ECB) (2010) bank performance is described as the bank's capacity to generate sustainable profits. The main drivers of bank performance are indicated by Bikker (2010) as costs, efficiency, profits and market structure.

\subsection{Determinants Of Bank Performance}

There are various studies that were conducted to identify the main determinants of bank performance, and different authors came with different conclusions. This implies that the determinants of bank performance are many and they range from firm specific to macro variables. In the study by Azam and Siddiqui (2011) the main determinants considered were capital adequacy, credit risk, liquidity, deposit growth, Gross Domestic Product (GDP), and inflation. For Sub Saharan Africa Flamini, McDonald and Schumacher (2009) highlight credit risk, capital size, market power, GDP and inflation as the main determinants of bank profitability. In Saudi Arabia, Ahmed and Khababa (1999) are of the view that business risk, market concentration, market size and size of the bank are the main determinants of bank profitability.

\subsection{Bank Liquidity On Bank Performance}

There are a very limited number of studies that were specifically carried out to investigate the impact of liquidity on bank performance. Surprising most of these few studies were done on manufacturing companies. Therefore, most of the studies reviewed in this study were mainly focused on finding determinants of bank profitability, of which liquidity was one of the determinants of profitability. Some writers found a positive relationship; some found a negative relationship while others found both results and a few found no relationship at all. The debate is still rampant.

Bourke (1989) in his study on performance of banks in twelve countries in Europe, North America and Australia found evidence that there is a positive relationship between liquid assets and bank profitability. These results seem counterintuitive, as it is expected that illiquid assets have a higher liquidity premium and hence higher return. Kosmidou, Tanna, and Pasiouras (2005) realised that the ratio of liquid assets to customer and short term funding is positively related to ROA and statistically significant. Also, they found a significant positive relationship between liquidity and bank profits. Kosmidou (2008) examined the determinants of performance of Greek banks during the period of EU financial integration (1990-2002) using an unbalanced pooled time series data set of 23 banks and found that less liquid banks have lower ROA. This is consistent with their previous findings like Bourke (1989) who found out that there is a positive relationship between liquidity risk and bank profitability. Recently, Olagunju, David and Samuel (2012) found out that there is a positive significant relationship between liquidity and profitability. They concluded that there is a bi-directional relationship between liquidity and profitability where the profitability in commercial banks is significantly influenced by liquidity and vice-versa.

On the contrary, Molyneux and Thornton (1992) recognized that there is inverse relationship between bank profitability and liquidity. They attributed this to the fact that banks hold liquid assets as an obligation to the requirements imposed by the authorities. However, if the author is to view this relationship from the context that banks hold liquid assets as mandated by the central bank or any other authorities, then the author may miss the argument as banks also hold liquid assets for other reasons. Assuming that banks only hold liquid assets as a requirement is, in itself, perfidious or a deliberate ignorance of knowledge of how banks function. Tobin (1958) advocated that liquidity is held for transaction purposes and for investments reasons. Tobin's proposal was a simplification of Keynes' liquidity preference theory. Keynes (1936) argued money is demanded for transaction, speculative, and precaution purposes. Therefore it can be firmly said without any prejudice that liquid assets over and above mandatory requirements are held for transaction, speculative and precautionary purpose.

Some authors found mixed results of both negative and positive relationship. Shen, Chen, Kao, and Yeh (2010) assert that in market-based financial system liquidity risk is positively related to net interest margin an indication that banks with high levels of illiquid assets receive higher interest income. Conflicting to their earlier establishment on the relationship with net interest margin, they realised that liquidity risk is negatively related to return on average assets and also inversely related to return on average equity. They pointed out that banks incurred higher funding cost in the market if they have illiquid assets as they had to raise the money in the market to meet the 
funding gap. They also discovered that there is no relationship between liquidity risk and performance in a bankbased financial system as the banks play a major role in financing; therefore they are not affected by liquidity risk. Demirgüç-Kunt and Huizinga (1999) had inconclusive results; they found a positive relationship between loans to total assets and the net interest margins. They also established an inverse relationship between the net interest margin and before tax profits. Ben Naceur and Kandil (2009) in their analysis of cost of intermediation in the postcapital regulation period which included; higher capital-to-assets ratios, an increase in management efficiency, an improvement of liquidity and a reduction in inflation found out that Banks' liquidity does not determine returns on assets or equity significantly.

Therefore conclusions about the impact of banks' liquidity on their profitability remain ambiguous and further research is required.

\section{DATA, EMPIRICAL MODEL SPECIFICATION \& ESTIMATION TECHNIQUES.}

In this section the researcher discusses the model specification and estimation techniques that were employed to address the main question of the linkage between bank liquidity and bank performance.

\subsection{Data Sources And Definition Of Variables}

This study used quarterly time series data for the period between 1998 and 2014 all data used in this study was obtained from McGregor data base, the central bank of South Africa (SARB) and Bloomberg. This study implemented market liquidity and funding liquidity measures proposed by Fungáčová and Poghosyan (2011). The markets liquidity risk is given as a ratio of liquid assets to current liabilities. Funding liquidity risk is represented by loan-to-deposit ratio.

The performance of the bank will be measured by the bank net interest margin as interest income minus interest expenses divided by total assets. Initially the regression model was run to investigate the deterministic relationship of the profitability as measured by net interest margin and liquidity. Then, in an attempt to establish a long-run co-integration relationship between liquidity and profitability the auto regressive distributed lag (ARDL) bounds testing approach by Perasan et al. (2001) model was adapted.

\subsection{Regression Model}

Market Liquidity Risk (LR), Credit Risk (CR), and Funding Liquidity Risk (FR) are incorporated into this equation to motivate a linear regression framework in equation 1.

$$
\left(R_{A}-R_{L}\right)=M L R+F L R+C R
$$

For the empirical estimation the relationship between net interest margin and the independent variables of liquidity and profitability can be expressed mathematically in equation 2 .

$$
N I M_{t}=\beta_{1} M L R_{i t}+\beta_{2} F L R_{i t}+\beta_{3} C R_{i t}+\varepsilon_{i t}
$$

The regression model was run to investigate the deterministic relationship of the Net interest margin and independent variables of liquidity risk, funding risk and credit risk. The F-statistic and P-values was used to establish the significance of the relationship between these variables and the results are presented in table 1. 
Table 1. F-Statistic Test for OLS

\begin{tabular}{lccc}
\hline \multicolumn{1}{c}{ Dependent Variable } & Function & F-Test Statistic & P-Value \\
\hline NIM & NIM(MLR) & 0.7819 & 0.3926 \\
NIM & NIM(FLR) & $11.3585^{* * *}$ & 0.0050 \\
NIM & NIM(CR) & 0.3130 & 0.5854 \\
\hline
\end{tabular}

*** Denotes $1 \%$ level of significance

** Denotes $5 \%$ level of significance

*Denotes $10 \%$ level of significance

Where NIM is the Net Interest Margin, following earlier studies, NIM is defined as interest income minus interest expenses divided by total assets, $M L R$ is the Ratio of Liquid Assets to current liabilities, proxying the market liquidity risk faced by banks, FLR is the Funding Liquidity Risk represented by loan-to-deposit ratio and CR is the Credit Risk where the ratio of provision for non-performing loans to total loans is used as an indicator. The results indicate that there is a negative significant relationship between NIM and FLR. The result is inconsistent with theory that attest to the fact that high and increasing loan-to-deposit ratio would lead to higher net interest margins (Fungáčová and Poghosyan, 2011). This shows a negative impact of the banks' funding model on their net interest margins. There is no significant relationship between net interest margin and the other two variables of market liquidity risk and credit risk. Again, this is a contrary to what theory and other empirical studies revealed. The estimated coefficient for liquidity risk is significant and negative as is the case in the previous studies that use similar definition of this variable to measure liquidity risk.

\subsection{Unit Root Tests}

Data sets of four variables (net interest margin, market risk liquidity, funding risk liquidity and credit risk) were tested for stationarity using Phillip-Perron and Augmented Dickey Fuller tests before they were tested for Cointegration using ARDL-bounds approach. The results of the stationarity tests on differenced variables are presented in Table 2.

Table 2. Stationarity Tests of Variables on First Difference -

Augmented Dickey Fuller (ADF) Test and Phillips-Perron (PP) Test

\begin{tabular}{lccc}
\hline Variable & Intercept & Trend \& Intercept & None \\
\hline \multicolumn{2}{l}{ Stationary tests of variables on fist difference - Augmented Dickey } & Fuller (ADF) test & $-4.1443^{* * *}$ \\
\hline DLNIM & $-3.9528^{* *}$ & $-3.7426^{*}$ & $-5.3372^{* * *}$ \\
DLMLR & $-5.1280^{* * *}$ & $-4.7674^{* *}$ & $-3.0180^{* * *}$ \\
DLFLR & $-2.9253^{*}$ & -2.9612 & $-4.8961^{* * *}$ \\
DLCR & $-4.6924^{* * *}$ & $-4.5167^{* *}$ & $-4.1443^{* * *}$ \\
\hline Stationary tests of variables on fist difference - Phillips - Perron (PP) test & $-5.3469^{* * *}$ \\
\hline DLNIM & $-3.9605^{* *}$ & $-3.7426^{*}$ & $-3.0209^{* * *}$ \\
DLMLR & $-5.1426^{* * *}$ & $-5.0481^{* * *}$ & $-5.2323^{* * *}$ \\
DLFLR & $-2.9291^{*}$ & -2.9130 & $-5.6879^{* * *}$ \\
DLCR & $-5.0032^{* * *}$ & & \\
\hline
\end{tabular}

*** Denotes $1 \%$ level of significance

** Denotes $5 \%$ level of significance

*Denotes $10 \%$ level of significance

The results reported in Table 2 show that after differencing, all the variables were confirmed to be stationary. The Augmented Dickey Fuller and Phillips-Perron tests applied to the first difference of the data series reject the null hypothesis of non-stationarity for all the variables used in this study. It is, therefore, worth concluding that all the variables are integrated of order one.

\subsection{Co-Integration Test- ARDL - Bounds Testing Procedure}

To establish a long-run Co-integration relationship between net interest margin and three independent variables the auto regressive distributed lag (ARDL) - bounds testing approach by Pesaran et al. (2001) model will be adapted. The ARDL approach is unique and superior in that it does not require all the variables under investigation to be integrated at the same order. Thus, the ARDL approach can be used in situation even if the 
regressors are integrated in any order that is order one $(\mathrm{I}(1))$, order zero $(\mathrm{I}(0))$ or partially integrated (Pesaran and Pesaran, 1997). Laurenceson and Chai (2003) argue that using the ARDL approach avoids problems resulting from non-stationary time series data.

The ARDL framework for equation 3, 4, 5, 6, 7, and 8 are as follows:

\section{Model 1 -Net interest margin and market liquidity}

$$
\begin{aligned}
& \Delta \ln \operatorname{NIM}_{t}=\mu_{0}+\sum_{i=1}^{n} \gamma_{1 i} \Delta \ln N I M_{t-i}+\sum_{i=1}^{n} \gamma_{2 i} \Delta \ln M L R_{t-i}+\gamma_{3} \ln N I M_{t-1}+\gamma_{4} \ln M L R_{t-1}+\varepsilon_{t} \\
& \Delta \ln M L R_{t}=\kappa_{0}+\sum_{i=1}^{n} \varphi_{1 i} \Delta \ln M L R_{t-i}+\sum_{i=1}^{n} \varphi_{2 i} \Delta \ln N I M_{t-i}+\varphi_{3} \ln M L R_{t-1}+\varphi_{4} \ln N I M_{t-1}+\varepsilon_{t}
\end{aligned}
$$

\section{Model 2 -Net interest margin and funding liquidity}

$$
\begin{aligned}
& \Delta \ln \operatorname{NIM}_{t}=\alpha_{0}+\sum_{i=1}^{n} \beta_{1 i} \Delta \ln N I M_{t-i}+\sum_{i=1}^{n} \beta_{2 i} \Delta \ln F L R_{t-i}+\beta_{3} \ln N I M_{t-1}+\beta_{4} \ln F L R_{t-1}+\varepsilon_{t} \\
& \Delta \ln F L R_{t}=\phi_{0}+\sum_{i=1}^{n} \rho_{l i} \Delta \ln F L R_{t-i}+\sum_{i=1}^{n} \rho_{2 i} \Delta \ln N I M_{t-i}+\rho_{3} \ln F L R_{t-1}+\rho_{4} \ln N I M_{t-1}+\varepsilon_{t}
\end{aligned}
$$

\section{Model 3 -Net interest margin and credit risk}

$$
\begin{aligned}
& \Delta \ln N I M_{t}=\pi_{0}+\sum_{i=1}^{n} \Omega_{1 i} \Delta \ln N I M_{t-i}+\sum_{i=1}^{n} \Omega_{2 i} \Delta \ln C R_{t-i}+\Omega_{3} \ln N I M_{t-1}+\Omega_{4} \ln C R_{t-1}+\varepsilon_{t} \\
& \Delta \ln C R_{t}=\psi_{0}+\sum_{i=1}^{n} \varpi_{1 i} \Delta \ln C R_{t-i}+\sum_{i=1}^{n} \varpi_{2 i} \Delta \ln N I M_{t-i}+\varpi_{3} \ln C R_{t-1}+\varpi_{4} \ln N I M_{t-1}+\varepsilon_{t}
\end{aligned}
$$

Where $\Delta$ is the first difference operator, $\varepsilon_{t}$ is the white noise operator. In the above equations, the terms with the summation signs represent the error correction dynamics while the second part (terms with $\gamma$ in equation (3), $\varphi$ in equation (4), $\beta$ in equation (5), $\rho$ in equation (6), $\Omega$ in equation (7), and with $\varpi$ in equation (8) correspond to the long run relationship. The null hypotheses in $3,4,5,6,7$, and 8 are $\gamma_{3}=\gamma_{4}=0, \quad \varphi_{3}=\varphi_{4}=0, \quad \beta_{3}=\beta_{4}=0, \quad \rho_{3}=\rho_{4}=0, \quad \varpi_{3}=\varpi_{4}=0$, and $\quad \Omega_{3}=\Omega_{4}=0$ respectively, which indicate the non-existence of the long run relationship. The first step of the ARDL- bounds testing requires examining the order of lags on the first differenced variables in equation 3, 5, and 7 using the Akaike information criterion (AIC) and the Schwartz-Bayesian criterion (SBC). The results of the AIC and the SBC suggest that optimal lag of NIM and MLR is 4, while the optimal lag for NIM and FLR is 1 and the optimal lag for NIM and CR is 4. The second step required us to apply the bounds F-test to equation 3, 4, 5, 6, 7, and 8 in order to determine whether any long run relationship between net interest margin and the independent variables under investigation exists. The results of the test for Co-integration are presented in table 3 . 
Table 3. Bounds F-test for Co-integration

\begin{tabular}{lll}
\hline Dependent Variable & Function & F-Test Statistic \\
\hline Model 1 -Net interest margin and market liquidity & & 0.3714 \\
\hline DLNIM & DLNIM (DLMLR) & $3.8560^{*}$ \\
DLMLR & DLMLR (DLNIM) & 0.3299 \\
\hline Model 2 -Net interest margin and funding liquidity & & $3.1521^{*}$ \\
\hline DLNIM & DLNIM (DLFLR) \\
DLFLR & DLFLR (DLNIM) & 0.6791 \\
\hline Model 3 -Net interest margin and credit risk & & 1.2334 \\
\hline DLNIM & DLNIM (DLCR) \\
\hline
\end{tabular}

*** Denotes $1 \%$ level of significance

** Denotes $5 \%$ level of significance

*Denotes $10 \%$ level of significance

The results show that there is no evidence of a long-run relationship between net interest income and provision for bad debts. All other things being equal net interest income is not influenced with the provision for nonperforming loans in the long run. To determine whether there is a unique co-integration vector in Models 1 and 2 , Table CI (III) as per Pesaran, Shin and Smith (2001:300), was used to decide on the asymptotic critical value bounds for the F-statistic since the models had unconstrained intercept and no trend. The lower and upper bounds for the Ftest statistic at the $10 \%, 5 \%$, and 1\% significance levels are [4.04 and 4.78], [4.94 and 5.73] and [6.84 and 7.84] respectively. As the values of the F-statistic are lower than the lower bound at the 1\% significance level, in this case it can be concluded that there is no unique Co-integration relationship between net interest margin and market liquidity risk and funding liquidity risk. Thus, the evidence revealed that there is no a long-run relationship between the two liquidity measures and net interest margin.

\section{CONCLUSION}

In this research, the relationship between the net interest margin and liquidity was estimated in South Africa using the OLS and the ARDL-Bounds testing approach. The researcher regressed the three independent variables, namely the current ratio, loan to deposit ratio and provision for non-performing loans as proxies for market liquidity, funding liquidity and credit risk respectively against the net interest income to total assets ratio, a proxy for net interest margin.

The results that are reported in this article are consistent with the view that there is a significant negative relationship between net interest margin and funding liquidity risk. Other findings here are also consistent with the findings of Maudos and Solis (2009) who found an insignificant relationship between net interest margin and market liquidity. Inconsistencies with the researcher's findings are findings by Maudos and Guevara (2004), and Saunders and Schumacher (2000) who found a significant positive relationship between market liquidity risk and net interest income.

Further tests indicated that there is no direct linkage between net interest margin and market liquidity, funding liquidity and credit risk in the long run. However, other scholars like Williams (2007) found a negative deterministic relationship between credit risk and interest margin in Australia where he interprets this finding as evidence that banks are unable to accurately price credit risk. In a more recent study carried in Russia, Fungáčová and Poghosyan (2011) also found a negative relationship between credit risk and net interest margin.

The overall results are broadly not in line with theoretical predictions, but they correspond to findings obtained in other studies on determinants of interest margin worldwide. Nevertheless, funding liquidity risk provided a lot of insight on the relationship between liquidity risk and net interest margin. Most of the previous studies focused on market liquidity than funding liquidity. It is therefore recommended that future studies on the determinants of net interest margin should investigate liquidity risk in the context of these two categories as well as systemic liquidity risk since investors need to be rewarded for holding illiquid assets and for the sensitivity of the security to liquidity shocks. 
An analysis of liquidity as having a direct linkage with net interest margin without incorporating liquidity spirals may be a major drawback in this study and other previous studies. It is suggested that future studies focus on the analysis of different liquidity categories and measures in the context of asset liabilities mismatches in determining its nexus with bank performance. An understanding of the interconnections between these elements will help better understand the slippery link between liquidity and performance of financial institutions.

\section{AUTHOR INFORMATION}

Godfrey Marozva is Chartered Financial Analyst (CFA) Charter-holder and has a Master of Science degree in Banking and Financial Services. He is currently a PhD candidate and is a lecturer at UNISA in the department of Finance, Risk Management and Banking. His main area of research interests include stock market development, bank performance, liquidity, portfolio management, derivatives, structured products, corporate finance, and risk management. E-mail: marozg@unisa.ac.za; godezhy@gmail.com

\section{REFERENCES}

Adler, D. (2012). The New Field of Liquidity and Financial Frictions. Research Foundation Literature Reviews, $7(2), 1-37$.

Ahmed, A. M., \& Khababa, N. (1999). Performance of the banking sector in Saudi Arabia. Journal of Financial Management and Analysis, 12(2), 30-36.

Azam, M., \& Siddiqui, S. (2011). Domestic and Foreign Banks' Profitability: Differences and Their Determinants. International Journal of Economics and Financial Issues, 2(1), 33-40.

Ben Naceur, S., \& Kandil, M. (2009). The impact of capital requirements on banks' cost of intermediation and performance: The case of Egypt. Journal of Economics and Business, 61(1), 70-89..

Bhunia, A., \& Khan, I. U. (2011). Liquidity management efficiency of Indian Steel Companies (a Case Study). Far East Journal of Psychology and Business, 3(3), 3-13.

Bikker, J. A. (2010). Measuring performance of banks: an assessment. Journal of Applied Business and Economics, 11(4), 141-159.

Bordeleau, É., \& Graham, C. (2010). The impact of liquidity on bank profitability (No. 2010, 38). Bank of Canada Working Paper.

Bourke, P. (1989). Concentration and other determinants of bank profitability in Europe, North America and Australia. Journal of Banking \& Finance, 13(1), 65-79.

Brunnermeier, M., Krishnamurthy, A., \& Gorton, G. (2013). Liquidity mismatch measurement. In Risk Topography: Systemic Risk and Macro Modeling. University of Chicago Press. Europe, North America and Australia. Journal of Banking \& Finance, 13(1), pp. 65-79.

Demirgüç-Kunt, A., \& Huizinga, H. (1999). Determinants of commercial bank interest margins and profitability: some international evidence. The World Bank Economic Review, 13(2), 379-408.

Drakos, K. (2003). Assessing the success of reform in transition banking 10 year later: an interest margin analysis, Journal of Policy Modeling, 25: 309-317.

European Central Bank. (2010). Beyond ROE-How to Measure Bank Performance.

Flamini, V., McDonald, C. A., \& Schumacher, L. B. (2009). The Determinants of Commercial Bank Profitability in Sub-Saharan Africa. IMF Working Papers, 1-30.

Fungáčová, Z., \& Poghosyan, T. (2011). Determinants of bank interest margins in Russia: Does bank ownership matter?. Economic systems, 35(4), 481-495.

Hesse, H. (2007). Financial Intermediation in the Pre-Consolidated Banking Sector in Nigeria, World Bank Policy Research Working Paper 4267.

Holmström, B., \& Tirole. J. (1998). Private and public supply of liquidity, Journal of Political Economy, 106, 1-40.

Keynes, J. M. (1936). The general theory of interest, employment and money.

Kosmidou, K., Tanna, S., \& Pasiouras, F. (2005). Determinants of profitability of domestic UK commercial banks: panel evidence from the period 1995-2002. In Money Macro and Finance (MMF) Research Group Conference (Vol. 45).

Kosmidou, K. (2008). The determinants of banks' profits in Greece during the period of EU financial integration. Managerial Finance, 34(3), 146-159. 
Laurenceson, J., \& Chai, C. H. (2003). Financial reform and economic development in China. Edward Elgar Publishing.

Markowitz, H. (1952). Portfolio selection*. The journal of finance, 7(1), 77-91.

Maudos, J. \& Guevara, J. (2004). Factors Explaining the Interest Margin in the Banking Sectors of the European Union, Journal of Banking and Finance, 28: 2259-2281.

Maudos, J., \& Solís, L. (2009). The determinants of net interest income in the Mexican banking system: An integrated model. Journal of Banking \& Finance, 33(10), 1920-1931.

Molyneux, P., \& Thornton, J. (1992). Determinants of European bank profitability: a note. Journal of Banking \& Finance, 16(6), 1173-1178. A note. Journal of Banking \& Finance, 16(6), pp. 1173-1178.

Olagunju, A., David, A. O., \& Samuel, O. O. (2012). Liquidity Management and Commercial Banks' Profitability in Nigeria. Research Journal of Finance and Accounting, 2(7-8), 24-38.

Pesaran, M. H., \& Pesaran, B. (1997). Working with Microfit 4.0: interactive econometric analysis; [Windows version]. Oxford University Press.

Pesaran, M. H., Shin, Y., \& Smith, R. J. (2001). Bounds testing approaches to the analysis of level relationships. Journal of applied econometrics, 16(3), 289-326.

Saunders, A. \& Schumacher, L. (2000). The determinants of bank interest margins: An international study, Journal of International Money and Finance, 19:813-832.

Shen, C., Chen, Y., Kao, L. \& Yeh, C. (2010). Bank liquidity risk and performance. International Monetary Fund, Working Paper.

Tobin, J. (1958). Liquidity preference as behavior towards risk. The review of economic studies, 65-86.

Williams, B. (2007). Factors determining net interest margins in Australia: domestic and foreign banks. Financial Markets, Institutions \& Instruments, 16(3), 145-165. 


\section{NOTES}

